\title{
CRIMINAL PUNISHMENT AND EARLY RELEASE PROGRAMS
}

Abstract: The punishment of criminals is a long-debated topic in penology, criminology, and sociology of law. But it has an underdeveloped history in philosophy generally, and in philosophy of law in particular. Philosophical discussions of early release programs is particularly lacking in philosophy of law and moral philosophy. But in the State of California, there are several citizens who believe that criminals ought to be treated with much more compassion than is currently the case (as they see it) and all that this seemingly implies, while there are those who argue for a compassionate but harsher treatment of criminals. This paper is an attempt to provide some philosophical clarity to some of the legal, economic and moral questions pertaining to whether or not proposed early release programs in California concerning criminal punishment are justified.

Keywords: Crime; Criminal rehabilitation; Cruel and unusual punishment; Early release programs; Ethics; Incarceration costs; Inmate worker programs; Punishment; Responsibility; Sentencing reform; State of California;

\section{Introduction}

There are multiple reasons provided in favor of criminal early release programs, where "early release" means that inmates are discharged from prison and placed on parole (or not) prior to serving their full legal sentences. Some of the reasons for early release programs include the moral, economic, and legal arguments. The moral argument for early criminal release programs holds that the State has a moral duty to demonstrate compassion toward criminal inmates and provide at least some of them with a second chance at making a better life within the confines of the law. This gives the inmates an opportunity to better themselves and society. It is hoped by proponents of this view that such subjects of early release are meaningfully rehabilitated. But this need not be the case as the parolee might be required to undergo counseling services for some time immediately subsequent to release.

The moral argument is often coupled with an economic argument for early criminal release which states that it is cost effective for the State to release certain lesser offenders

\footnotetext{
1 acorlett@mail.sdsu.edu
} 
earlier than their original sentences require. This enables the State to shift the funding that would otherwise be spent on incarcerating such offenders on their parole programs and other criminal justice needs. Or, it might also be used to save the State a certain percentage of that would have otherwise gone toward the incarceration of said inmates.

One version of the legal argument for criminal early release programs relies on perceived illegal conditions of incarceration which require, it avers, the rectification of those conditions in order to comply with legal standards. It is often argued, for instance, that prison conditions are unpalatable and require reform in order to satisfy federal and/or state constitutional prohibitions against cruel and unusual punishments.

I shall argue that neither one of these arguments is unproblematic. The moral argument begs the question concerning the nature and role of compassion in the realm of criminal justice. It also ignores critical components of criminal justice which are required for a morally sound criminal justice system. The economic argument is problematic, I shall argue, because it is unclear that early release programs saves the State money on balance, all relevant things considered. While it is obviously true that criminal early release programs permit the State to reallocate or save funds which would have otherwise been used to incarcerate such inmates, such a maneuver comes at a high cost and in the end is not cost effective as is often believed. The legal argument has force. However, it is unclear that early release programs are the best answer to such problems of prison abuse. There are other available options which do not require the increase of public funds in order to satisfy the legal prohibition against cruel and unusual punishments. So neither the moral nor economic nor legal arguments serve to justify criminal early release programs. It is not that moral, economic and legal considerations are not vital to matters of criminal justice. It is, rather, that such arguments do not in the end justify criminal early release programs.

Furthermore, it should be noted that the ethics of criminal early release programs ought not to be discussed absent recognition of the importance of establishing and maintaining proven viable crime prevention programs such as drug and alcohol rehabilitation programs, parenting programs, personal finance programs, after-school education and athletic programs and head start programs for legal minors. These and other such social programs are important parts of a more general strategy of reducing crime and providing all citizens with an equal opportunity to succeed. For criminal early release programs themselves are not unproblematic in that they more often than not release offenders right back into the poor neighborhoods form where they originate. Generally, such programs have the inadvertent result of placing an undue burden on poor neighborhoods in having to experience the high recidivism rates of early released offenders. This alone serves as an argument from unfairness concerning the typical administration of such programs.

In 2009, a United States federal court composed of a three judge panel declared the State of California prison system to be overcrowded and in violation of the cruel and unusual punishment clauses of both the $8^{\text {th }}$ Amendment to the U.S. Constitution and Section 17 of the Constitution of the State of California because it did not provide adequate medical and mental health care for inmates.

The court's order grows out of two cases filed against the state, one in 1990 and the other in 2001. In one, lawyers for inmates argued that medical care in California prisons was so poor that it was unconstitutional. In the other, attorneys contended that mental health care was similarly under par (Bernstein, 2013). 
Thus the Court tied the prison inmate population issue to that of the State of California criminal justice system's failure (in the mind of the Court) to provide adequate medical and mental healthcare for the inmates. The Court apparently believed that this problem is a violation of the federal and State constitutional right not to incur cruel and unusual punishment and that the decreasing of California inmates would allow the State to better provide for the medical and mental healthcare of its inmate population. The Court specified that the State inmate population must be decreased by 30,000. (L. Davis, 2011)

The current Governor of the State of California, Jerry Brown, has worked at reducing State prison populations in order to comply with the Court's mandate by transferring 25,000 State inmates to county jails. However, his office has recently asked the Court to vacate its original mandate because, it argued, for it to order the release of additional prisoners in order to completely satisfy the original mandate of the Court would pose a public safety problem and the State's budget is suffering in significant part due to the fiscal implications of fulfilling the Court's mandate. "More than $\$ 2$ billion has been allocated by the state to help local governments handle their new responsibilities, while another $\$ 1.7$ billion in state bonds is going to build more county jail space." (Thompson, 2013)2 Furthermore, Deborah Hoffman, a spokesperson for the California Department of Corrections and Rehabilitation, said the State had spent more than $\$ 1$ billion reducing overcrowding and improving medical care in its prisons: "Since 2006, the inmate population in the state's 33 prisons has been reduced by more than 43,000 ... Any further reduction of the prison population is unnecessary and unsafe." (Bernstein, 2013)

Moreover, the federal judges in question waived all California State laws in June 2013 as they ordered Brown to expand good-time credits leading to early release. They also directed the him to take other steps, including sending more inmates to firefighting camps, paroling elderly felons, leasing cells at county jails and slowing the return of thousands of inmates now housed in private prisons in other states. If those steps fail to sufficiently reduce the inmate population in California State prisons, the judges ordered the State of California to release by the end of 2013 enough inmates from a list of lower-risk offenders until it reaches the maximum allowed population (Elias, 2013). Thus it is clear that the noted efforts to force the State of California to comply with perceived constitutional requirements to eliminate cruel and unusual punishment by way of overcrowding and inadequate medical and mental healthcare is linked to criminal early release programs.

Legal, economic and moral considerations come into play together in this scenario, thereby raising at least the following important questions: Is the Court's ruling correct that the inmate population in California prisons violates the cruel and unusual punishment clauses of the U.S. and State constitutions, and is it genuinely cruel and unusual to continue to house inmates in the crowded conditions in question? Furthermore, is the early release of offenders (even some serious ones) a fiscally responsible manner by which to reduce the inmate population in California prisons? Does it cost the State of California less to incarcerate inmates than to release them early in order to avoid the prolonging of the general State fiscal crisis? And even if the early release of many offenders is a fiscally

\footnotetext{
2 Moreover, "The Department of Corrections and Rehabilitation reported 119,213 inmates on January 2, just under 150 percent of capacity but above a 137.5 percent target." - See more at: http:// www.freeinews.com/united-states/brown-must-reduce-california-prison-population-federaljudges-rule\#sthash.Enzm2vm9.dpuf.
} 
viable means to help resolve the State's prison population problems, does it do so at too high a cost to the citizens of the State, thereby violating their rights to reasonable peace and tranquility and general protections by the State? Or can the Court's mandate be satisfied in some other constitutionally, morally and economically viable manner, assuming that all other means of reducing prison inmate populations have been attempted in good faith, but have not sufficed to meet the demands of the Court's mandate?

There are thousands of lesser criminals in the California criminal justice system, and the State's ongoing economic challenges pose questions concerning to how to handle the sentencing and punishment of such criminals. On average, it costs at least $\$ 60,000$ per year to house a criminal in a California prison, and when these criminals are senior inmates, the cost of incarceration can double, and sometimes triple due mostly to the costs of medical care for such prisoners. (Penner \& Faryon, 2010)

In order to better understand the problems facing the State of California in terms of its high-cost prison system, it is important to clarify much of the reasoning behind the skyrocketing costs, including very highly paid unionized prison guards, increasingly high costs of prison construction, increasing costs of healthcare and medical care for inmates. It is important to note that the State of California provides some of the best prison services for its inmates than most prisons worldwide. One need only compare the prison conditions of inmates in California prisons with inmates in various prison systems in Mexico, Central and South America, and various other countries, and it is plain to see that inmates in California prisons are treated very well: For instance,

Those of us who have been inside California's prisons and jails know better. Prison floors, yards, and other common areas are cleaned regularly, with the floors shined to a high gloss. Inmates have their own bed, mattress, linens, clothing, and toiletries, with two hot meals and one sack lunch per day, and nearly unlimited access to dental, medical, and psychiatric care. Inmates also have access to the law library (with assistance offered), visits from family, conjugal visits (if married and not incarcerated on a life term), legal visits, exercise yard, chapel (with religious guidance), vocational programs (from welding to commercial diving), educational programs (remedial, GED, and higher education), and self-help programs such as anger management, parenting, and Alcoholics and Narcotics Anonymous. California prisons have strict rules for report writing, the use of force, respect toward inmates (no swearing), and a zero tolerance on the code of silence or dishonesty of its officers. Inmates are offered a grievance process, which is taken seriously by prison administrators and often results in either a confidential fact-finder inquiry process or an internal affairs investigation process, and their access to the courts to sue their jailers may not be impeded. (Coleman, 2014)

It is vital to understand that most, if not all, of these provisions are lacking in most prisons outside the U.S.. So it is rather misleading to assert that California prisons are either inhumane or cruel without careful qualification that such prisons are being held to a very high standard of compliance to a particular model of what counts as cruel and unusual punishment in terms of prison conditions.

"Cruel and unusual," then, is quite the relative locution. So one must be ever careful in asserting this or that condition in a California prison is inhumane, or otherwise a violation of the cruel and unusual punishment clause of the $8^{\text {th }}$ Amendment. To the extent that this is the case, it is incumbent on those who describe California's prisons as being ei- 
ther cruel or inhumane to support their perspective with rational argument and empirical evidence, rather than with dogmatic ideological insistence that the treatment in question amounts to such. Even on the assumption that California State prisons are overcrowded, such a condition is hardly "unusual" in terms of prisons both in the U.S. and globally. So the issue here is whether or not the conditions in said prisons are cruel.

Generally, it is argued by many that the $8^{\text {th }}$ Amendment to the U.S. Constitution and the Constitution of the State of California place by way of their "cruel and unusual punishment" clauses a duty on the State of California to treat its inmates in ways that do not violate these protections as they are interpreted by many. Thus medical care and an assortment of other goods and services are on this view considered to be positive claim rights of inmates and correlative duties of the State to provide to inmates. Simply because someone has violated the rights of others, no matter how viciously, does not imply the loss of certain rights of the criminal-no matter how costly it is for the State to fund the inmate's life while in prison, and even outside it should she be paroled. ${ }^{3}$ I shall return to this argument below.

In addition to the cruel and unusual punishment clauses of said constitutions, other arguments might be provided in support of treating inmates with compassion. One such reason is that many such inmates have been rehabilitated and no longer pose a realistic threat to society. If they are paroled, it would cost California taxpayers substantially less than it would cost them if those criminals were incarcerated. Indeed, thousands of such criminals have recently been released (in part) in order to save such costs. The conditions of the State of California's budget, then, have justified in the minds of many the recent early release of thousands of lesser offenders.

But it might be replied that the recidivism rate of such criminals is an empirical question, and it is unclear whether the costs saved by releasing them from prison early will equal or rival the cost of the criminals' recidivistic behavior once released. Here I refer not only to the costs associated with incarceration of such inmates to the State, but the costs of releasing mostly recidivists to law-abiding citizens and businesses within the State.

Given the "steady" illegal drug use among the far majority of California prisoners (whether or not the crimes that landed them in prison were drug-related), it is naïve to think that such drug use will not continue when such users are paroled, leading to various sorts of drug-related criminal behavior, including DUIs. For example, while it costs at least $\$ 60,000$ per year to incarcerate a typical California inmate (Graves, 2013), there is a high probability that $\mathrm{s} /$ he is one of the illegal drug users in prison and is likely to use such drugs when released as many California inmates use illegal drugs even while incarcerated (Thompson, 2014). If s/he commits a DUI and kills or maims someone other than herself while on early release, the cost of that former inmate's behavior to Californians is staggering, in the millions of dollars in terms of at least both restitutional costs and the costs of lost productivity of the injured party or parties often times per incident, ${ }^{4}$

\footnotetext{
${ }^{3}$ Indeed, there are those who believe that in large part because the current prison system is overly harsh and thus unfair and unjust to criminals that the prison system has reached a point of obsolescence (A. Y. Davis, 2003; 2005).

4 This estimate includes, of course, the costs of personal injuries, if duly compensated. Given considerations of fairness, and given that the average settlement in California for cases of Catholic priestly child sexual abuse is over $\$ 1,000,000$, the injuries and other damages caused by a DUI can easily exceed this amount per incident.
} 
often more than the at least $\$ 60,000$ to house that prisoner per year or the few millions it would cost to incarcerate that prisoner even as a lifer. If that early released former inmate suffers from a drug overdose, the cost of health care for that single overdose is far greater than the cost of housing that criminal in prison for one year, ${ }^{5}$ and many drug users suffer multiple overdoses in a year or over a lifetime. Furthermore, those criminals who are unlikely to commit violent crimes might well (and often do) find identity theft their crime of choice, thereby wreaking havoc to the tune of hundreds of thousands to millions of dollars on the lives of many individual innocent taxpaying citizens. ${ }^{6}$ And let us become ever mindful that an inmate on early release can, in committing her crimes, traumatize innocent citizens, some who are (or are likely to become) among the most valuable and productive ones in the State of California. How to measure such victim trauma is rather difficult. But courts decide such matters on a regular basis. Cummulatively, the cost of early released recidivistic criminals on their victims in terms of trauma can be moderately estimated to amount to at least $\$ 1$ billion USD per year, calculated at an estimated rate of at least $\$ 1$ million USD per DUI caused by early released inmates per victim and per victim's loved ones. Added to this estimated cost is the trauma of victims of early released inmates committing residential burglaries, auto thefts, etc., at a rate of about $\$ 100,000$ USD per incident and per individual victim. If only 1,000 early released inmates committed such crimes against residents of California, the total cost for only this factor of early released criminal recidivism would amount to at least $\$ 1$ billion USD per year. It is likely that Governor Brown understood this and much more as he struggled to convince the judges of the unreasonableness of their demand. Implicit in Governor Brown's stance on this matter is a version of the ethical principle that "ought implies can," meaning that if one has a duty to do something, it must be able to do so. Obviously, Governor Brown believes that the State of California has no duty to comply with the ruling of the panel because it cannot do so without causing undue harm to itself. And it is the main point of this article to reason through several factors relevant to this problem of criminal early release programs to better understand whether or not they are reasonable-especially in contemporary California.

So there are several realistic and highly likely scenarios in which lesser criminals, if released early and given an average recidivism rate of drug-related criminal activity, can cause far more damage to law-abiding Californians (or others) than it would cost to continue to house them in the prison system for the duration of their respective terms. Added to these problems is the cost to the State of California of additional parole officers in order to monitor the influx of thousands of additional parolees into California cities and towns. And accompanying such crimes, of course, are significant economic costs that such criminals never bear: the costs of their recidivistic incarceration, trials, and law enforcement and emergency personnel at the scenes of their recidivistic crimes, as well as personal injuries and property damages to law abiding citizens, etc.. So the argument that it costs more to house a lesser criminal than it does to release her early is problematic when these factors are taken into consideration. For the argument neglects to mention the full range

${ }^{5}$ I personally have seen the bills of some such cases, wherein in each case the combined HMO hospital drug overdose costs exceeded $\$ 100,000$ including only a three day hospital stay.

${ }^{6}$ http://www.irs.gov/uac/Examples-of-Identity-Theft-Schemes-Fiscal-Year-2013: Accessed on 14 April 2014. 
of costs of the lesser criminal's recidivistic crimes to her immediate victims as well as to the State. These factors seem to be absent from the many calls for early release in the State of California.

However, the point just made fails to take into consideration the possible rehabilitation of some prisoners. As mentioned above, one reason in favor of the early release of lesser offenders in the State of California is that many inmates are rehabilitated from a life of crime to a "better" life and no longer pose a threat to society. They have for years "proven" themselves to be "model" prisoners and can be trusted now to go back into society and live as decent citizens. To continue to incarcerate them especially in desperate economic times is foolish at best, contributing their part to an economic collapse at worst. Thus rehabilitated lesser prisoners ought to be released in order to significantly lessen the State of California's economic woes.

But while there is little doubt that a small percentage of criminals are criminally rehabilitated in some meaningful sense of the term, there is no credible empirical evidence supporting the widespread successful rehabilitation of even lesser offenders. As is common knowledge, prisons generally take criminals and, albeit inadvertently, make "better" criminals out of most them, and in the process deepens most inmates' psychological problems and sociopathic tendencies. Of course, a reasonable person should not expect a different outcome when some of the most dysfunctional folk (others, of course, include many "innocent, law-abiding" citizens) in a society are forced to live together for years and under impalpable conditions compared to the rest of us. Moreover, rehabilitative institutions do not have strong track records concerning the successes of their patients. Thus it is dubious that genuine or successful criminal rehabilitation is sufficiently widespread amongst even lesser criminals in the California State prisons to justify the release of massive numbers of those lesser criminals into society in order to help resolve the State of California's fiscal challenges. Criminal recidivism, then, is the likely future of most of those who are on programs of early release and probation.

Furthermore, if some or all lesser criminals in California somehow become rehabilitated while serving their time in prison, this is a good thing. But is it a sufficiently good reason for their early release and parole? What about what a criminal deserves in light of the facts of her crime (including mitigating factors) and the damages she has caused to others for which she can scarcely pay in economic terms? Besides, part of genuine rehabilitation is that the offender admit full responsibility for her crime, and own up to (compensate) what she owes her victims in terms of the factors mentioned above, including the state's costs of incarcerating her. What if genuine rehabilitation entails that the offender rectify her wrong by compensating her victim(s), including the state? (Corlett, 2014) If genuine rehabilitation implies genuine apology by the offender to her victim(s), and if a genuine apology entails that the offender compensate her victim(s), then the mere stipulated fact that a prisoner will not likely repeat her crime or even another crime is insufficient reason for her early release as it ignores considerations of justice and fairness. It violates principles of desert, proportionality and responsibility. I assume here that no theory of punishment which ignores these factors can be taken seriously. Thus the rehabilitation of offenders is insufficient reason for their early release-even if it were granted (in all unlikelihood) that that criminal will not engage in recidivistic behavior that would further cost victims and the state in economic and personal terms. 
But early release programs suffer from a further malady, one briefly alluded to above. As Joel Feinberg argues, there cannot be a moral right to something in scarce supply (Feinberg, 1973, pp. 94-96). To the extent that a moral "ought implies can," then, there is no moral right to goods and services for inmates should the State of California not be able to afford them under reasonable conditions of justice, or under reasonably just conditions-including economic ones. So even if it were true that California inmates deserve increased rather than decreased quality of conditions of incarceration, it would not follow that they ought to have such rehabilitative treatment should the costs of such treatment be genuinely unreasonable. And it is this idea of how such criminals should be treated that the "ought implies can" principle seeks to question. Even if there were a viable method or program of criminal rehabilitation, it is unreasonable to think that the state can afford to rehabilitate so many criminals, or that it should have to bear that significant economic burden. If any party has the moral burden and ought to have the economic burden, it should be the criminals themselves and their supporters. This is especially true given certain assumptions about criminal liability, namely, that the criminal offenders in question are duly convicted and that they satisfy the conditions necessary and sufficient for criminal liability for their offenses and that there exist no significant mitigating circumstances which would justify the lessening of their sentences. To the extent that an inmate is responsible for her crime and deserves the sentence she receives, that is the extent to which she, as part of her sentence, owes the State to compensate it and her citizen and business victims for the full range of costs of her criminal activity that duly landed her in prison. The early release and paroling of lesser criminals, then, must attach to it a legal expectation with consequences for non-compliance that such costs of an inmate's crimes be borne solely by the inmate herself. To some extent, this is already required in California when certain restitutional fines are imposed on some criminals. ${ }^{7}$

But let us assume for the sake of argument that each and every inmate in a California prison is totally and unequivocally rehabilitated, including serious and non-serious offenders alike. Let us further assume that all criminologists concur that such criminal offenders will live model citizen lives if released from prison and that their criminal recidivism rates will be zero. And let us further assume that if the California prisons are emptied of all lesser offenders in this way that in large part the economic challenges of the state will be resolved, as billions of dollars each year once used for prison operations can now be used to balance the state's annual budget, and that the state's prison guard union is assured that its members will be provided viable employment elsewhere within the system so that they are not displaced. Does it follow that even under this utopian scenario that the inmates in question ought to be released prior to the completion of their respective sentences?

The answer to this question depends on how seriously one takes the justice and fairness-based concepts of deservedness, responsibility, and proportionate punishment, mentioned above. On a desert-based view, the very idea of releasing such inmates-whether to balance the State's budget or because the inmates are truly rehabilitated (or both) amounts to a denial of some of the most fundamental moral values that form the basis of any reasonably just society, or one seeking to become reasonably just. For the question at hand fails to consider what the criminals deserve on the basis of their respective levels

7 http://www.vcgcb.ca.gov/restitution/: Accessed on 14 April 2014. 
of responsibility for what they did to others in terms of significant harmful wrongdoing. In so doing, it violates considerations of proportionate punishment. Assuming as we are that the prisoners in question were duly convicted and are responsible to a meaningful extent for what they did to others in terms of committing crimes against them, it violates proportionate punishment considerations to release them early for whatever reasons. This assumes, again, the reasonableness of their sentences imposed by the state. Thus the question of early release of criminals is out of the question when these basic moral precepts are taken seriously. Whatever cost saving measures are needed in California, they ought not to run counter to what justice requires; they ought not to make nonsense of deservedness, responsibility, and proportionate punishment. Any plausible approach to balancing California's budget must not run afoul of these vital moral and legal considerations.

Indeed, responsibility without compassion is heartless toward criminals, but compassion absent responsibility is disrespectful of the rights of victims of crimes. ${ }^{8}$ There need not be an unresolvable tension between holding criminals accountable for their harmful wrongdoings to the extent that they are responsible for them, on the one hand, and treating them at least comparatively (to other criminal inmates the world over) rather well, on the other. Given the assumptions already laid bare, this implies that the very idea of "early" release of criminals is unjustified, as criminals ought to serve their prison sentences as part of what they deserve for what they have done, all relevant things considered.

But if early release and parole of criminals is morally out of the moral question, then are there other ways to evade the problems facing California concerning its economic challenges and the extent to which its prison system contributes to that problem? While there are those who call for prison reform in terms of "inmates' rights," that approach, as I have explained, only deepens the economic challenges of the State, and it also runs afoul of not taking seriously considerations of desert, responsibility and proportional punishment. So the support of inmates rights, while not without some due consideration especially where there are genuine abuses in prisons against prisoners, hardly addresses the problem at hand absent creating other serious ones.

Making California prisons easier on inmates runs the serious risk of not punishing offenders according to what proportionality dictates in light of the relevant facts of their respective cases. Moreover, it fails to hold duly convicted criminals responsible for the full extent of their harmful wrongdoings to others, all mitigating factors considered. It is not a solution to the problem at hand to simply refuse to punish offenders seriously, where "punishment" entails hard treatment (Feinberg, 1970). Prison reform must work both ways: It must seek to eliminate the abuse of prisoners (an ever-worsening problem both in terms of frequency and harshness), and it must also strive toward giving them their genuine due in light of the facts of each case, including the severity of the harms they have wrongfully wrought on others. In short, prison reform must also include sentencing reform. And while there are cases wherein criminals are over-sentenced or over-punished (especially where racism and classism are present in the sentencing of such offenders), there exist numerous cases of serious crimes which are instances of under-punishment or overly light sentencing given the full range of facts of the cases and in light of principles of proportionate punishment (Corlett, 2014).

${ }^{8}$ Victims of crimes, of course, include both the direct and indirect victims, and the harms resultant from the crimes against them can and often do have lasting effects. 
However, what if prison reform instead adopted an inmates' rights and responsibility perspective? Instead of only seeking to make things easier for inmates no matter what harmful wrongdoings they have committed, the system ought to hold them truly accountable for their crimes according to proportionality considerations while protecting them from prison-specific abuses in the process. After all, while prison sentences are not supposed to include basic rights abuses of offenders, prison terms are supposed to amount to hard treatment and a reasonable range of what that entails in terms of deprivations for the criminals in light of the amount of harm caused to innocents, including the State, citizens and businesses directly affected by the crimes. Both utilitarians and desert-based theorists can agree on this point (though for different reasons, of course), and it would take an abolishionist (sometimes cast in terms of a rehabilitationist) stance on punishment to deny it (Menninger, 1968; Boonin, 2008; Coleman, 2014). ${ }^{9}$ The law, like morality, must always expect and demand a modicum of reasonableness and fairness amongst cognitively normal adults. Thus whatever else is relevant to the possible early release and parole of California inmates for the above stated fiscal aims, matters of desert, responsibility and proportionality must be given due consideration.

There are a myriad of ways to interpret the cruel and unusual punishment clauses of the $8^{\text {th }}$ Amendment to the U.S. Constitution and the Constitution of the State of California. And it is likely that the framers and ratifiers of these constitutions deliberately chose to not be precise about what they mean by "cruel and unusual," as with other important terms throughout those documents. One possible reason for this is given the kind of documents they are, the framers and ratifiers wanted to leave it up to each generation of citizens and lawmakers to decide what constitutes cruel and unusual punishment. ${ }^{10}$ Indeed, it is likely that the framers and ratifiers had deep disagreements among them as to the meaning of this locution. It is reasonable, then, to think that terms like "cruel and unusual" punishment need to be decided by way of sound argument and analysis from one generation to the next. In light of this possibility, what indeed constitutes cruel and unusual punishment relative to the sentencing and punishment of serious criminals in the State of California?

It is unreasonable to think that not providing the extent of medical care that the State of California currently does provide inmates is a violation of the cruel and unusual punishment clause. ${ }^{11}$ What counts as cruel and unusual is in part a relative matter. And it amounts to an ad hominem fallacy to insist that whatever happens in other "less enlightened" societies in terms of prison treatment is morally incorrect because it violates the cruel and unusual punishment clause in question. Why is it cruel and unusual to not provide inmates with as much healthcare benefits as the State of California currently does, a level of medical care not enjoyed by millions of U.S. citizens themselves, not to mention hundreds of millions of persons throughout the world? For that matter, why is it a violation of the cruel and unusual punishment clause to not provide inmates with many of the

${ }^{9}$ Such a standpoint was championed, of course, by the famous trial lawyer, Clarence Darrow.

${ }^{10} \mathrm{I}$ borrow this point from a discussion with Joel Feinberg in 1990.

${ }^{11}$ Note that what is not being argued here is that because of California's fiscal challenges, whatever rights to healthcare inmates possess should be violated in order to resolve the said challenges. That would be tantamount to arguing that rights can be violated during extreme emergencies, a view that effectively denies rights. On this point of the importance of rights over social utility considerations (Rawls, 1971, pp. 3-5). 
other goods and services that the state currently does? Again, I crucially assume here that each criminal in question is duly convicted of her crime and is serving an appropriate sentence for it in light of any meaningful mitigating factors present in her case.

Moreover, moral intuitions vary greatly on what counts as prison over-crowding and cruel and unusual conditions in the State of California prison system. And when proportionality considerations are taken seriously, it is difficult to imagine what a sound non-question-begging and proportionality-respecting argument might look like which defends the status quo in California prisons insofar as provisions for criminal offenders are concerned.

Precisely what moral rights do inmates have and what legal rights should inmates have? By this I do not mean to ask what legal rights they possess, as the answer to that question is generally a matter of simply considering the criminal laws of the State of California (and federal laws which supersede them). Rather, what I mean to ask is what moral rights they have, which is another way of asking what legal rights they ought to have. But it is precisely this question which, among other things, forces the reconsideration of what counts as cruel and unusual punishment.

If "ought implies can" is true, then it is unreasonable for the State of California to be expected to provide the level of medical care for inmates which it is currently expected to provide by the panel of federal judges if it seeks to one day return to a long-term healthy and sustainable economy. While rights cannot be trumped by social utility considerations (otherwise, as John Rawls argues, they would not be rights), claims to rights are not absolute. Context and circumstance must determine their validity. This point should register to those who believe that in general poor economic conditions often lead to crime and often legitimately mitigate sentencing of offenders (Shelby, 2007, pp. 126-160). So those who hold that view should be sensitive to the health of the State of California's declining economic conditions because it is the improvement of the State of California's economy that can and in various ways assists in the prevention of criminal activity, generally speaking. In mind here are the various citizen assistance programs for the needy (mentioned above), some of which have proven to have important results in crime prevention among the young, providing many such citizens with hopes for viable futures. But can the State of California continue to afford the level of medical and mental healthcare it currently provides for its offenders, much less significantly increased levels of medical and mental healthcare? It seemingly cannot do so now given the skyrocketing costs of healthcare in general.

Perhaps the State of California needs to question the interpretation of the constitutional cruel and unusual punishment clauses under consideration here, and the State's policy of inmate treatment which bolstered the provision of comparatively extraordinary medical and mental healthcare benefits to even the most heinous offenders. Perhaps the State of California needs to garner the moral courage to reject as unreasonable the view of prison reform which effectively fails to punish duly convicted and strongly responsible criminals in proportion to their harmful wrongdoings, including the diminishing of medical care and certain other services to such inmates. Perhaps the State of California needs to find the moral courage to hold fast to its reasonable expectation of responsibility for behaviors of all of its normal cognizing citizens (mitigating factors considered), while providing an adequate measure of care for those who genuinely require mental healthcare. 
But what there is no adequate argument for is the current state of affairs wherein the State of California remains economically challenged in significant part because many of its citizens, elected officials, judges and other law enforcement officials refuse to provide the sound and non-question-begging arguments in favor of how the status quo amounts to unduly punishing serious criminals who are strongly culpable for their crimes according to how badly they harmed others. Until this is accomplished, the current criminal justice system is in need of reform, but not generally in the way of easing inmates' lives, but rather in terms of making their punishments better "fit" their crimes in terms of the amount of harm caused to others by their crimes. This measure has the desired effect of providing inmates with a punishment they deserve (however approximately), without continuing to bankrupt the Golden State.

In the end, it would appear that this problem of the moral status of early release programs for criminals rests on moral intuitions about what constitutes cruel and unusual punishment in light of what inmates genuinely deserve in terms of the extent to which they have as culpable agents wrongfully harmed others. On the one hand, most will concur that no matter what the crime(s), no matter how heinous and wrongfully harmful to others, such offenders ought not to be, say, drawn and quartered, lit afire or otherwise physically tortured to death-even if such punishments would amount to under-punishments for certain cruel and unusual offenders. Even the retributivist and capital punishment advocate Immanuel Kant argued that the state's punishment of criminals ought to be humane (Kant, 1965). However, that the State of California has a moral duty to provide the level of medical care it currently provides inmates is also morally controversial. That it would violate inmates' alleged rights to certain other goods and services should it cease providing the current level of inmate support is also questionable. Comparatively speaking, most prisons throughout the world are far less congenial to prisoners than California prisons are to their inmates. But even non-comparatively, it is not obvious that the current state of affairs in California prisons violates "human rights" of prisoners, or that the State's reducing the goods and services it provides for prisoners is a violation of whatever rights prisoners ought to have, regardless of class, ethnicity, or gender.

There are, then, various reasons why the State of California might reconsider its fundamental moral values underlying its current treatment of its inmate populations, and it might do so by reevaluating its interpretation of the cruel and unusual punishment clause of the federal and State constitutions. It is a sign of an inhumane society to over-punish its serious offenders. But it is an overly compassionate society indeed which-especially in the midst of serious and ongoing economic challenges--refuses to muster the moral courage to punish its criminals according to reasonable principles of proportionate punishment.

While it is true that the facts of the cases of many inmates requires mitigated sentencing, such considerations can and are taken into account by way of the amount of time served. But this hardly counts against the idea that such offenders ought to be punished in ways that amount to hard treatment and the deprivation of various privileges and effective waiving of certain rights enjoyed by law-abiding citizens. Moreover, it hardly amounts to a refutation of the idea that the State of California is spending far too much on the incarceration of serious offenders. For those who, say, disfavor State, County and City budget cuts which would target public education, it is reasonable to think that a far better as- 
pect of those budgets to target is the criminal justice system. Perhaps dogmatic ideologies ought to be set aside in favor of a reasonable pursuit of what is just and fair for the State of California and each of its citizens-both the law-abiding and inmates alike.

However, not only is it dubious to think that it saves money to release many prisoners and parole them earlier than their respective sentences dictate, there are various ways in which incarcerating inmates can be achieved at a much lower cost than is currently the case in California. If it is true that the California Correctional Peace Officers Association (CCPOA) is one of the most powerful in the State perhaps the significant taming of that union's stranglehold on the State's budget is in order. Insofar as the cost of incarcerating inmates is decreased in this regard, substantial progress would be made in reining in the costs of California's prisons without the implementation of early release programs. For the cost savings there could be applied to the costs of expanding existing prisons to house inmates under improved conditions congruent with the Court's mandate.

A further strategy in reducing the costs of incarceration in California is the transfer of inmates with substantial and clinical mental health problems to mental health facilities where they are more appropriately treated. However, while this maneuver will save on incarceration costs, it is likely to be a substantial cost transferred to the State of California in terms of mental health costs for such persons. Mental health care professionals are not inexpensive. Perhaps it ought to be an increased line-item of the State's budget to humanely subsidize the adequate treatment of such persons as it is hardly their fault that they suffer from such mental problems. Perhaps a shifting of their prison incarceration costs to various mental health treatment centers would suffice to treat such persons--both in-patient and out-patient. A treatment plan such as this is likely to have a meaningful and positive effect on the reduction of suicides and mass shootings. Just as important, it might enable mental health sufferers to become survivors and live more meaningful, productive and enjoyable lives.

The release of inmates incarcerated due to their commission of drug-related offenses into community-based drug rehabilitation programs supervised by the parole system can save the state millions of dollars per year as the placement of such persons from prisons to rehabilitation in-patient housing is less expensive for the State and far more appropriate for the patients (Justice Policy Institute, 2010). However, unless such treatment succeeds to a meaningful degree, these cost savings ignore the costs of such offenders to law-abiding citizens in terms of DUI violations which eventuate in many deaths, maimings, etc. of citizens who shall not, realistically speaking, be compensated for their wrongful harms by such current inmates. Nor does it consider the real costs of the many burglaries and other such crimes committed by such offender drug addicts prior to their completing successful treatment. The costs of early releases of the drug-related kind in significant part transfer the costs of criminality from the State to private citizens who are victimized by the recidivistic behaviors of drug users on early release and parole programs.

Of course, there is one method of both respecting the demands of justice in punishment and reducing costs of incarceration: forcing able-bodied inmates to work manual and other forms of labor to offset the costs of prisons as much as possible. This also includes the use of, say, inmate workers on public projects like the building or repairing of roadways, bridges, the picking of produce, or any other labor that can significantly assist in economic terms. Many states already impose such work on inmates at a fraction of the 
cost of unionized labor, making the forced criminal labor a win-win for the businesses and the inmates alike (though more of a win for the businesses). Many states, like the State of Arizona, provide such paid labor. ${ }^{12}$ However, it is an interesting question whether or not states ought to consider requiring unpaid labor incentivized by granting productive inmate laborers with various forms of free time to pursue various incarcerated activities that they currently enjoy without having to otherwise earn. Such labor as a form of punishment is, of course, protected by the $13^{\text {th }}$ Amendment to the U.S. Constitution and by the Constitution of the State of California (Article 1, Section 18). Moreover, since "punishment" is by definition to constitute hard time, then there should be no apologies in working inmates full-time without monetary compensation. Should they be physically unable to work manual labor, they can be forced to perform as much unskilled non-manual work that they are able to perform in order to offset as much of the costs they are incurring on society as possible while serving their time in prison. For their entire "income" generated from their 40-hour work weeks throughout the year while incarcerated would, I argue, be paid directly to the State of California in order to help off-set the costs of their incarceration. At $\$ 5$ per hour for each inmate employed at about 100,000 inmates working 40 hours per week all year, plenty of funds can be generated to essentially substantially lower the costs of incarceration in California prisons. In effect, inmates would be forced to work mostly manual labor for their time served-an excellent way to teach them to not commit crimes. Whatever the cost residue each released inmate incurs while in prison, that amount shall stand as a fine to be paid by the offender once or if released and shall be paid back to the State of California up to $50 \%{ }^{13}$ of earnings she receives until the debt is paid in full (Most inmates would die before they pay their dues in full).

Of course, as I argue elsewhere, those wrongly incarcerated should receive substantial exoneration compensation by the State and have their criminal records automatically expunged at no cost to such victims of the criminal justice system, and those who through criminal negligence were primarily responsible for their wrongful incarceration ought to be punished as outlined in the California Penal Code and have their assets seized in order to help compensate their victims who were wrongly imprisoned. But if the State is able to manage prisoner resources well, there is a chance that their labor power can produce enough surplus labor value (to use Karl Marx's terminology) to offset the costs of incarceration even if the prisoner is unable to work off enough to fully compensate her $\operatorname{victim}(\mathrm{s})$. This teaches such adult offenders to become and remain responsible citizens. This proposal would constitute a form of "responsible compassion" at least in terms of the system's not punishing duly convicted inmates with strict proportionality.

Of course, reducing the cost of incarcerating criminals is just one manner by which the State of California can in part become and remain fiscally responsible. Programs which prevent crime ought to be supported in the overall effort to satisfy budgetary requirements, and ought also to be considered to work in concert with the criminal justice system. Providing various programs to the most needy for the aim of achieving equal opportunity in life's prospects has made and should continue to make significant progress

12 http://www.azcorrections.gov/prisons/Prisca_Prisons_Perryvil.aspx/: Accessed on 14 April 2014.

13 This percentage is consistent with that which is taken from each criminal's earnings from various California and federal agencies in order to provide restitution to her victims. See http://www. vcgcb.ca.gov/restitution/: Accessed on 14 April 2014. 
toward the eliminating the conditions that provide the circumstances of much criminal activities (Shelby, 2007, pp. 126-160). The State must make these and other decisions in order to become economically viable once again, and to remain so. And this requires the judicious implementation of reasonable laws and sentences for those who commit fraud against the system that is designed to assist them along these and related lines. For contrary to those who believe that welfare fraud by the needy is in some cases "legitimate" and represents an affront to a system that is deemed by many of the needy as being insensitive to their plight (Shelby, 2007, pp. 126-160), that such criminals effectively deprive other needy citizens of much needed resources and thereby worsening their lives ought to be considered in any legislation and sentencing of such fraud.

Moderate measures (responsible compassion) must be taken to balance the State's approach to sustainable living for all of its citizens. While there is no need to construct additional prison facilities because some (prison building contractors among them) have convinced the State of California that it is a "human rights" violation to have what is perceived to be over-crowding, several more prisoners can be housed in most existing prisons, making them even less attractive to anyone considering or reconsidering a life of crime. What the State of California does not need are additional increasingly expensive (eg., supermax) prisons (to my knowledge, there are no inexpensive ones), dramatically increasing the average cost of incarceration. Prison building contractors must be taken at the lowest bids and including foreign competitors who can drive those bids far lower than they have been for several years. This implies that politicians who are "influenced" by private contractors who seek to profit from the construction and maintenance of the prison industrial complex must be exposed, terminated, charged, tried and if duly convicted for their fraud, sentenced to substantial prison terms and coerced to provide restitution to the State.

Substantially reducing the costs of incarceration by eliminating various amenities for inmates, and by making them work full-time without compensation is in no way a human rights abuse, nor a violation of the cruel and unusual punishment clauses of the U.S. and State constitutions. It is, rather, to hold responsible offenders responsible for what they do to illicitly harm others in proportion to the harms they cause. Inmates can be economically exploited in order to substantially reduce their costs to the State and their direct citizen and business victims, and perhaps in some cases to actually turn a profit from their malfeasance. However, businesses should never be allowed to turn a profit from inmate laborers until the State and crime victims are fully reimbursed for their costs that are incurred by said inmate laborers. In doing so, a genuine sense of responsible compassion must be instilled among Californians. In any case, California must refuse to continue to resolve its budget crisis, insofar as it is partly the result of exorbitant expenses regarding the criminal justice system, on the backs of its law-abiding citizens. At the very least, State revenues should not be raised to cover the perceived increased costs of incarceration until at least the avenues explored herein have been given due consideration. 
Џ. Анџело Корлет ${ }^{1}$

Сан Дијего Државни Универзитет

Сан Дијего, Калифорнија (САД)

\title{
КРИВИЧНЕ САНКЦИЈЕ И ПРОГРАМИ РАНОГ ОТПУСТА ЗАТВОРЕНИКА
}

\author{
(Превоg In Extenso)
}

Сажетак: Кажњавање криминалаца је, као тема, дуго предмет дебате у пенологији, криминологији и социологији права. У филозофији уопште, међутим, има неразвијену историју, а посебно у филозофији права. Филозофски разговори о програмима раног отпуста посебно мањкају филозофији права и филозофији морала. У држави Калифорнији је више грађана који верују да би криминалце требало третирати са много више саосећања него што је то тренутно случај (из њихове перспективе) уз све што то наизглед имплицира, док има и оних који се залажу за саосећајнији али и оштрији третман криминалаца. Овај рад је покушај да се обезбеди филозофска јасноћа неких правних, економских и моралних питања која се односе на то да ли су предложени програми раног отпуста у Калифорнији код кривичнх санкција оправдани.

Кључне речи: криминал, рехабилитација криминалаца, окрутна и неуобичајена казна, програми раног отпуста затвореника, етика, затворски трошкови, програми рада затвореника, казна, одговорност, реформа казненог система, држава Калифорнија

\section{Увод}

Постоји више аргумената који иду у корист програмима раног отпуста, где „рани отпуст” значи да се затвореници пуштају из затвора условно (или не) пре него што у потпуности одслуже изречену казну. Неки од разлога за програме отпуста укључују моралне, економске и правне аргументе. Морални аргумент за програме раног отпуста код кривичних санкција јесте у моралној дужности државе да демонстрира саосећање према затвореницима и бар некима од њих да другу шансу како би створили бољи живот у оквирима закона. Ово затвореницима пружа прилику да унапреде како сами себе, тако и друштво. Заговорници оваквог мишљења се надају да су они који су рано ослобођени претходно значајно рехабилитовани.

1 acorlett@mail.sdsu.edu 
Међутим, то не мора бити случај, јер се од ослобођеног може тражити да посећује саветника неко време након пуштања на слободу.

Морални аргумент је често повезан са економским аргументом за рани отпуст, у којем се наводи да је за државу економично да ослободи одређене мање прекршиоце раније него што то захтевају њихове првобитно изречене казне. То држави омогућава да пребаци средства, која би иначе била потрошена на затварање таквих преступника, на програме условног отпуста и друге потребе кривичног правосуђа. Такође, постоји могућност уштеде одређеног процента новца који би иначе био потрошен на затварање прекршиоца закона.

Једна верзија правног аргумента за програме раног отпуста ослања се на уочене нелегалне услове затварања који, с друге стране, захтевају испуњавање тих услова како би се ускладили са законским стандардима. Често се тврди да су затворски услови лоши и да су потребне реформе како би се задовољиле савезне и/или државне уставне забране окрутних и неуобичајених казни.

Тврдићу да ниједан од ових аргумената није непроблематичан. Морални аргумент поставља питање у вези са природом и улогом саосећања у области кривичне правде. Он такође игнорише критичне компоненте кривичног правосуђа које су неопходне за морално исправан систем кривичног правосуђа. Економски аргумент је проблематичан, тврдићу, јер је нејасно да ли програми превременог отпуста штеде државни новац, узимајући у обзир све релевантне чињенице. Иако је очигледно тачно да програми раног отпуста омогућавају држави да преусмери или уштеди средства која би иначе била коришћена за затворске трошкове, такав маневар носи високе трошкове и на крају није економичан као што се често верује. Правни аргумент има силу. Нејасно је, међутим, да ли су програми раног отпуста најбољи одговор на проблеме злостављања у затворима. Има и других могућих опција које не захтевају повећање јавних средстава како би се задовољила законска забрана окрутних и неуобичајених казни. Дакле, ни морални, ни економски, ни правни аргументи не могу оправдати програме раног отпуста затвореника. То не значи да морални, економски и правни разлози нису од виталног значаја за питања кривичне правде. Ради се о томе да такви аргументи, на крају, нису довољно оправдање за програме раног отпуста затвореника.

Штавише, треба напоменути да о етичности програма раног отпуста затвореника не треба дискутовати без признавања важности успостављања и одржавања доказаних одрживих програма за спречавање криминала, као што су програми рехабилитације од дроге и алкохола, програми родитељства, програми личних финансија, школско образовање и спортски програми, као и програми за пружање подстрека малолетницима. Ови и слични социјални програми представљају важне делове опште стратегије за смањење криминала и обезбеђивање једнаких могућности за све грађане. Програми раног отпуста затвореника су проблематични, јер често долази до пуштања прекршилаца закона назад у сиромашне средине из којих су потекли. Уопштено говорећи, такви програми садрже нехумани резултат стављања непотребног терета на сиромашне заједнице, јер морају да искусе високу стопу рецидивизма рано ослобођених преступника. Сама ова чињеница служи као аргумент неправичности у погледу типичне примене таквих програма. 
Током 2009. године, савезни суд Сједињених Држава, састављен од три судије, прогласио је затворски систем Калифорније пренатрпаним уз присутно кршење клаузула о окрутним и неуобичајеним казнама, како 8. амандмана Устава САД, тако и члана 17 Устава Калифорније, јер затвореницима није пружао адекватну медицинску и менталну заштиту. ${ }^{2}$ Према томе, суд је проблем броја затвореника повезао са неуспехом кривичног правосуђа у Калифорнији (из перспективе суда) да обезбеди адекватну медицинску и менталну здравствену заштиту затвореника. Суд је очигледно веровао да је овај проблем кршење савезног и државног уставног права да не дође до окрутних и неуобичајених казни и да ће смањење броја затвореника у Калифорнији омогућити држави да боље осигура медицинску и менталну заштиту своје затворске популације. Суд је прецизирао да се број затвореника мора смањити за 30.000. ${ }^{3}$

Тренутни гувернер Калифорније, Џери Браун (Jerry Brown), радио је на смањењу броја затвореника у државним затворима како би га ускладио са одлуком суда пребацујући 25.000 затвореника из државних у окружне затворе. Његова канцеларија је, међутим, недавно затражила од суда да преиначи своју првобитну одлуку. Како се тврди, ослобађање додатног броја затвореника због потпуног задовољавања првобитне одлуке суда представљало би проблем јавне безбедности, док државни буџет већ у великој мери пати због фискалних импликација испуњавања одлуке суда. ${ }^{4}$ Осим тога, Дебора Хофман (Deborah Hoffman), портпарол калифорнијске службе за корекције и рехабилитацију, изјавила је да је држава потрошила више од милијарду долара смањујући пренасељеност и унапређујући медицинску заштиту у својим затворима: „Од 2006. године, број затвореника у 33 државна затвора смањен је за више од 43.000 ... Свако даље смањење затворске популације је непотребно и небезбедно."

2 „Одлука суда је донешена на основу две тужбе подигнуте против државе, једне из 1990. године, а друге из 2001. године. У првој, адвокати затвореника су тврдили да је здравствена заштита у затвору у Калифорнији толико лоша да је неуставна. У другој, адвокати су тврдили да је ментална заштита на сличан начин неуставна. Sharon Bernstein, Brown Must Reduce California Prison Population, Federal Judges Rule, Reuters, 12. април 2013: http://www. freeinews.com/united-states/brown-must-reduce-california-prison-population-federal-judgesrule: приступљено 12. априла 2013. године.

3 Lois Davis, California's Prisoner Shuffle, The Los Angeles Times, 19. август 2011: http://articles. latimes.com/2011/aug/19/opinion/la-oe-davis-prisoners-state-prisons-20110819: Приступљено 19. августа 2011.

4 „Држава је издвојила више од две милијарде долара како би помогла локалним властима у вези са новим одговорностима, док ће са још око 1,7 милијарди државних обвезница платити изградњу додатног простора у окружним затворима." (Види Don Thompson, Calif. Struggles with Experiment to Shift Inmates, Associated Press, 12. мaj 2013: http://news.yahoo.com/ calif-struggles-experiment-shift-inmates-133428169.html: Приступљено 12. маја 2013. Додатно, The Department of Corrections and Rehabilitation reported 119,213 inmates on January 2, just under 150 percent of capacity but above a 137.5 percent target - Види више на: http://www. freeinews.com/united-states/brown-must-reduce-california-prison-population-federal-judgesrule\#sthash.Enzm2vm9.dpuf.)

${ }^{5}$ Bernstein, Brown Must Reduce California Prison Population, Federal Judges Rule, Reuters, 12. април 2013: http://www.freeinews.com/united-states/brown-must-reduce-california-prison-population-federal-judges-rule: Приступљено 12. априла 2013. 
Осим тога, савезне судије су у јуну 2013. године ставиле у страну све законе Калифорније, јер су наредиле Брауну да прошири листу кредита за добро владање који воде ка раном отпусту. Такође су наложиле да предузме друге кораке, укључујући слање више затвореника у ватрогасне кампове, условно пуштање старијих криваца, изнајмљивање ћелија у окружним затворима и успоравање повратка хиљада затвореника смештених у приватним затворима у другим државама. Ако ти кораци не успеју да довољно смање број затвореника у државним затворима у Калифорнији, судије су наложиле држави Калифорнији да до краја 2013. године ослободи довољно затвореника са списка прекршилаца лакших кривичних дела док не достигне максимално дозвољену популацију. ${ }^{6}$ Стога је јасно да су поменути напори да се Калифорнија присили да поштује уставне захтеве за елиминацијом окрутног и неуобичајеног кажњавања због пренасељености и неадекватне медицинске и менталне здравствене заштите у вези са програмима за рани отпуст затвореника.

Правна, економска и морална разматрања иду руку под руку у овом сценарију и постављају се следећа важна питања: да ли је одлука суда да број затвореника у Калифорнији крши клаузуле савезног и државног Устава о окрутним и неуобичајеним казнама исправна и да ли је заиста окрутно и неуобичајено да се настави са држањем затвореника у поменутим условима? Штавише, да ли је рани отпуст преступника (чак и неких озбиљних) фискално одговоран начин да се смањи број затвореника у затворима у Калифорнији? Да ли Калифорнију мање кошта да затворенике држи или да их рано пусти на слободу како би избегла продужење опште државне фискалне кризе? Чак и ако је рани отпуст преступника фискално одрживо средство за решавање проблема затворске популације, да ли то подразумева превисоку цену коју треба да плате грађани, чиме држава нарушава юихова права на мир и спокој и општу заштиту? Да ли се одлука суда може задовољити на неки други уставно, морално и економски одржив начин, под претпоставком да је покушано са другим начинима смањења броја затвореника, али да они нису били довољни да задовоље захтеве судске одлуке?

Има на хиљаде лакших прекршилаца у систему кривичног правосуђа Калифорније, а тренутни економски изазови државе постављају питања која се тичу начина приступа изрицању казне и кажњавању таквих криминалаца. У просеку, најмање 60.000 долара годишње кошта издржавање преступника у затвору у Калифорнији, а када су у питању старији затвореници, трошкови затварања могу се удвостручити, а понекад и утростручити због трошкова медицинске заштите. ${ }^{7}$

Да би се боље разумели проблеми са којима се суочава држава Калифорнија у погледу свог скупог затворског система, важно је разјаснити разлоге високих трошкова, укључујући високо плаћене синдикалне затворске чуваре, високе трошкове изградње затвора, повећање трошкова здравствене заштите затвореника. Важно је

${ }^{6}$ Paul Elias, California Prison Early Release Plan Won't Be Delayed, Supreme Court Rules, Huff Post, Los Angeles, 2. август 2013.: http://www.huffingtonpost.com/2013/08/02/california-prison-earlyrelease_n_3698348.html: Приступљено 2. августа 2013.

7 http://www.kpbs.org/news/2010/jan/08/overcrowded-and-expensive-governor-addresses-calif/. Приступљено 13. јула 2010. 
напоменути да Калифорнија пружа неке од најбољих затворских услуга својим затвореницима у односу на већину затвора широм света. Потребно је само упоредити затворске услове у Калифорнији са условима у различитим затворским системима у Мексику, Централној и Јужној Америци и разним другим земљама да би се јасно видело да се затвореници у затворима у Калифорнији третирају веома добро (Coleman, 2014): на пример, ми који смо били у калифорнијском затвору знамо боље. Затворски подови, дворишта и остали заједнички простори се редовно чисте, а подови се рибају до високог сјаја. Затвореници имају властити кревет, душек, постељину, одећу и тоалетне потрепштине, уз два топла оброка и један ручак у кеси дневно, уз готово неограничен приступ стоматолошкој, медицинској и психијатријској нези. Заточеници такође имају приступ правној библиотеци (уз помоћ), право на посете породице, брачне посете (ако су у браку и нису затворени доживотно), правне посете, двориште за вежбање, капелу (са свештеником), стручне програме (од вариоца до комерцијалног роњења), едукативне програме (здравствено, средње и високо образовање) и програме самопомоћи, као што су управљање бесом, родитељство и програм Анонимних алкохоличара и уживаоца наркотика. Калифорнијски затвори имају строга правила у вези са писањем извештаја, употребом силе, поштовањем затвореника (без псовања) и нулту толеранцију у погледу кршења кода тишине или непоштености својих службеника. Осуђеницима је на располагању поступак за жалбе који управа затвора схвата озбиљно и који често доводи до поверљивих истрага ради утврђивања чињеничног стања или поступка унутрашње контроле, на начин да приступ судовима ради тужбе против радника затвора не може бити ометен (Coleman, 2014).

Важно је схватити да већина ових ставки, ако не све, недостају у већини затвора изван САД. Прилично је погрешно, дакле, тврдити да су затвори у Калифорнији нехумани и окрутни без узимања у обзир чињенице да ти затвори држе веома висок стандард усклађености са одређеним моделом и оним што тај модел сматра окрутном и неуобичајеном казном у смислу затворских услова.

„Окрутна и неуобичајена” је, према томе, релативна одредница. Мора се увек пажљиво потврдити да је ово или оно стање у затвору у Калифорнији нехумано, или да на други начин крши клаузуле о окрутним и неуобичајеним о казнама 8. амандмана. У оној мери у којој сматрају да је тако, они који описују затворе у Калифорнији као сурове или нехумане, дужни су да подрже своју перспективу рационалним аргументима и емпиријским доказима, а не с догматским идеолошким инсистирањем на томе да је третман такав, каквим је описан. Чак и под претпоставком да су државни затвори у Калифорнији пренатрпани, такво стање је тешко „неуобичајено” када је реч о затворима у Сједињеним Државама и на глобалном нивоу. Зато, питање је да ли су услови у поменутим затворима окрутни.

Уопштено говорећи, многи тврде да 8. амандман савезног Устава и Устава државе Калифорније својом клаузулом против „сурових и неуобичајених казни” намеће држави дужност да третира своје затворенике на начин који не крши ове заштитне мере онако како их тумачи већина. Стога се медицинска нега и скуп других добара и услуга по овом мишљењу сматра позитивним правима затвореника и корелативном дужношћу државе да их затвореницима пружи. То што је неко прекр- 
шио права других, без обзира на то колико озбиљно, не значи губитак одређених сопствених права - без обзира на то колико је држави скупо да финансира живот затвореника у затвору, па чак и изван њега у случају условног отпуста. ${ }^{8}$ Вратићу се на овај аргумент у наставку.

Осим клаузула поменутих устава о окрутним и неуобичајеним казнама, могу се изнети и други аргументи који би подржали саосећајно поступање са затвореницима. Један од таквих разлога је то што су многи такви затвореници рехабилитовани и више не представљају реалну опасност за друштво. Ако би били условно пуштени, то би коштало пореске обвезнике у Калифорнији знатно мање него што би их коштало да су ти криминалци затворени. Заиста, хиљаде таквих криминалаца недавно је пуштено (делимично) како би се смањили трошкови. Стање државног буџета Калифорније, у том моменту, оправдало је, многи верују, недавни рани отпуст хиљада лакших починилаца.

Може се рећи, међутим, да је степен рецидивизма оваквих криминалаца емпиријско питање и није јасно да ли ће трошкови раног отпуста бити једнаки или већи од трошкова насталих у случају да криминалци понове кривична дела. Овде се не позивам само на трошкове који се односе на затварање таквих починилаца, већ и на трошкове отпуста углавном рецидивиста међу грађане и пословне субјекте који поштују закон у држави.

С обзиром на то да је „стална” употреба наркотика међу већином затвореника у Калифорнији (без обзира на то да ли су злочини због којих су у затвору били у вези с дрогом), наивно је мислити да се таква употреба дроге неће наставити када добију отпуст, што доводи до различитих врста криминалног понашања у вези с дрогом, укључујући и вожњу под дејством наркотика. На пример, иако затварање типичног криминалца у Калифорнији кошта најмање 60.000 долара годишње (Graves, 2011), постоји велика вероватноћа да је он један од нелегалних корисника дрога у затвору и вероватно ће користити такве дроге када добије отпуст, будући да много затвореника у Калифорнији користи илегалне супстанце чак и у затвору (Thompson, 2014). Ако он/она вози под дејством наркотика и тако повреди или убије неког другог док је на условном отпусту, трошак понашања бившег затвореника за држављане Калифорније је огроман и мери се милионима долара у смислу реституцијских трошкова и трошкова изгубљене продуктивности оштећене стране или страна, па и по појединачном инциденту, ${ }^{9}$ што је често више од 60.000 долара годишње колико кошта да се тај затвореник налази у затвору или неколико милиона у случају да је на издржавању доживотне казне. Ако се тај рано отпуштени бивши затвореник предозира, трошак здравствене заштите за то једно предозирање далеко је већи од трошкова збрињавања у затвору

8 Заиста, постоје они који верују да је то што је садашњи затворски систем претерано оштар и стога неправедан према прекршиоцима у великој мери разлог томе што је затворски систем достигао тачку застарелости (А. Y. Davis, 2003; 2005)

9 Ова процена обухвата, наравно, трошкове личних повреда, ако су прописно надокнађене. С обзиром на принцип правичности и имајући у виду да је износ просечне нагодбе у Калифорнији за случајеве сексуалног злостављања деце од стране католичких свештеника више од 1.000.000 долара, повреде и друга штета проузрокована вожњом под дејством наркотика лако може премашити тај износ по инциденту. 
у трајању од једне године $\mathrm{e}^{10}$, а многи корисници дрога преживе више случајева предозирања годишње или током животног века. Штавише, они криминалци који нису склони насилним злочинима могу (често) вршити крађу идентитета као злочин избора, чиме се ствара штета која се мери стотинама хиљада до милион долара у животима многих невиних пореских обвезника. ${ }^{11}$ Будимо све-сни да затвореник на раном отпусту може, при извршењу својих злочина, трауматизовати невине грађане, неке који су (или ће вероватно постати) међу највреднијим и најпродуктивнијим у држави Калифорнији. Како мерити такву трауму жртава, прилично је тешко питање. Судови редовно одлучују о таквим стварима. Кумулативно, трошак који рано пуштени повратници стварају у погледу трауме може се умерено проценити на износ од најмање једну милијарду долара годишње, рачунато по процењеној стопи од најмање један милион долара по штети коју затвореник на раном отпусту изазове по жртви вожњом под утицајем наркотика. На овај процењени трошак треба додати трауме жртава рано пуштених повратника који проваљују у станове, краду аутомобиле и слично, по стопи од око 100.000 долара по инциденту и по појединачној жртви. Ако је само 1.000 рано пуштених повратника починило такве злочине против становника Калифорније, укупни трошкови за само овај фактор рецидивизма повратника на раном отпусту износили би најмање једну милијарду долара годишње. Вероватно је гувернер Браун ово схватио и боље, јер се борио да убеди судије у неразумност њиховог захтева. Оно што се имплицира у ставу гувернера Брауна о овом питању је верзија етичког принципа који каже да „потреба имплицира могућност”, што значи да ако је неко дужан нешто да уради, мора бити у стању то и да учини. Очигледно је да гувернер Браун сматра да држава Калифорнија није дужна да се придржава одлуке судија, јер не може то да учини без наношења штете самој себи. То је главна поента овог чланка, разматрање неколико фактора који су релевантни за проблем програма раног отпуста како би се боље разумело да ли су они разумни или не, посебно у савременој Калифорнији.

Има, дакле, неколико реалистичних и веома вероватних сценарија у којима

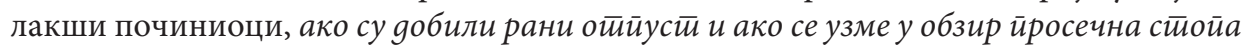

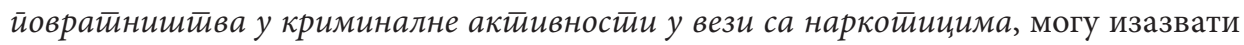
много више штете грађанима Калифорније који поштују закон (или другима) него што кошта да они остану у затвору током трајања изречене казне. Овом проблему треба додати трошак Калифорније на додатне службенике који треба да прате додатни прилив неколико хиљада затвореника на условном отпусту у калифорнијске градове. Уз такве злочине, наравно, иду значајни економски трошкови које никада не подносе сами криминалци: трошкови њиховог поновног затварања, личне повреде и штета на својини грађана, итд. Према томе, аргумент да државу више кошта да лакше криминалце држи затвореним него да их рано отпусти јесте проблематичан када се ови фактори узму у обзир. Тај аргумент не уважава пун спе-

10 Лично сам видео рачуне у неким таквим случајевима, у којима су у сваком случају комбиновани трошкови болничког лечења премашили 100.000 долара, укључујући само три дана боравка у болници.

11 http://www.irs.gov/uac/Examples-of-Identity-Theft-Schemes-Fiscal-Year-2013: Приступљено 14. априла 2014. 
ктар трошкова злочина који почини лакши криминалац у односу на своје жртве и државу. Ови фактори нису присутни код многих заговорника раног отпуста у Калифорнији.

Ипак, ставка коју смо управо изложили не успева да узме у обзир могућу рехабилитацију неких затвореника. Као што је већ споменуто, један разлог који иде у прилог раном отпусту лакших преступника јесте тај да су многи затвореници рехабилитовани из живота са криминалом у „бољи” живот и више не представљају претњу по друштво. Они су током година „доказали” да су „узорни” затвореници и да им се може поверити повратак у друштво уз узоран живот. Наставити њихове затворске дане, нарочито у очајним економским тренуцима, у најмању руку је несмотрено, што само доприноси економском колапсу. Према томе, рехабилитоване лакше прекршиоце треба ослободити како би се значајно смањиле економске тешкоће државе Калифорније. Иако нема сумње да је мали проценат криминалаца рехабилитован на неки смислен начин, не постоје основани емпиријски докази који иду у прилог тврдњи о широкој успешној рехабилитацији затвореника. Као што је опште познато, затвори често ненамерно направе „боље” криминалце од већине њих и током тог процеса продубе њихове психолошке проблеме и социопатске тенденције. Наравно, неразумно је очекивати другачији исход када су неке од најдисфункционалнијих особа (други, наравно, укључују многе „невине”, „поштене” грађане) у друштву натеране да годинама живе заједно под много горим условима у односу на све нас. Штавише, институције које обављају рехабилитацију немају довољно добре податке у вези са успехом својих пацијената. Према томе, сумњива је тврдња да је успешна рехабилитација криминалаца довољно распрострањена чак и међу лакшим криминалцима да би се оправдало пуштање огромног броја тих криминалаца у друштво како би се решили државни фискални изазови. Повратништво у криминал је, дакле, вероватна будућност већине оних укључених у програме раног отпуста и условне слободе.

Додатно, ако неки или сви лакши криминалци у Калифорнији буду некако рехабилитовани током одслужења казне, то је добра ствар. Али, да ли је то довољно добар разлог за њихово рано пуштање на слободу и условну слободу? Шта је са оним што криминалац заслужује у светлу чињеница о свом злочину (укључујући олакшавајуће факторе) и штете коју је нанео другима, а коју тешко да може да плати у економском смислу? Осим тога, део истинске рехабилитације јесте да починилац призна пуну одговорност за свој злочин и да преузме на себе (надокнади) оно што дугује жртвама у смислу наведених фактора, укључујући и затворске трошкове. Шта ако истинска рехабилитација подразумева да је учинилац исправио своју кривицу тако што је надокнадио штету жртви (жртвама), укључујући и државу? (Corlett, 2014). Ако истинска рехабилитација подразумева искрено извињење починитеља жртви и ако се под искреним извињењем подразумева да починилац надокнади штету жртви (жртвама), онда утврђена чињеница да затвореник вероватно неће поновити свој злочин или чак неки други злочин сама по себи није довољан разлог за рани отпуст на слободу, јер игнорише поимање правде и правичности. То крши принципе пропорционалности и одговорности. Претпостављам да нема теорије о кажњавању која игнорише ове факторе, а која се може озбиљно схватити. Рехабилитација преступника, дакле, 
није довољан разлог за њихов рани отпуст на слободу - чак и ако се може гарантовати (колико год то невероватно изгледало) да се тај криминалац неће упустити у рецидивистичко понашање које ће додатно коштати жртве и државу у економском и личном смислу.

Програми раног отпуста пате од још једне болести која се у горњем тексту кратко спомиње. Као што тврди Џоел Фајнберг, не може бити моралног права на нешто што је дефицитарно (Feinberg, 1973, str. 94-96). Што значи да, у погледу максиме „потреба имплицира могућност”, не постоји морално право које затвореници имају на робу и услуге уколико држава Калифорнија не може да их приушти под разумним условима правде или под разумно правичним условима - укључујући и оне економске. Чак и ако је истина да затвореници у Калифорнији заслужују повећање, а не смањење квалитета затворских услова, не значи да би требало да имају такав рехабилитацијски третман уколико су трошкови таквог третмана стварно неразумни. То је управо идеја како са таквим злочинцима треба поступати, а коју испитује принцип „потреба имплицира могућност”. Чак и ако постоји одржив метод или програм рехабилитације криминалаца, неразумно је мислити да држава може себи да приушти рехабилитацију толико много криминалаца или да мора поднети то значајно економско оптерећење. Ако било која странка носи морални терет и треба да има економски терет, то треба да буду сами криминалци и њихове присталице. Ово је посебно тачно с обзиром на оgређене ирреитиосииявке о кривичној оgі̄o-

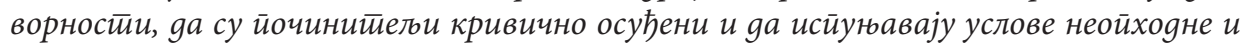
gовољне за кривичну одіоворносй за своја кривична gела и gа не йосйоје значајне олакшавајуће околности које би оиравgале сманенье юихових йресуgа. Мера у којој је затвореник одговоран за своје кривично дело и у којој заслужује изречену казну јесте мера до које је он, као део казне, дужан држави и грађанима да надокнади штету и пуне трошкове својих криминалних активности због којих је у затвору. Раном отпусту лакших преступника на слободу и условну слободу онда треба додати правно очекивање, с последицама за непоштовање, за трошкове злочина осућеника које сносе искључиво они сами. У одређеној мери, то већ постоји у Калифорнији при изрицању одређених казни за накнаду штете неким криминалцима. ${ }^{12}$

Али, претпоставимо ради овог разговора да је сваки затвореник у калифорнијском затвору потпуно и недвосмислено рехабилитован, укључујући лакше и теже прекршиоце. Дозволите да, даље, претпоставимо да се сви криминалисти слажу да ће такви кривични прекршиоци живети узорним животом ако буду пуштени из затвора и да ће стопа њиховог рецидивизма бити равна нули. Претпоставимо, даље, да ће затвори у Калифорнији, ослобођени свих мањих преступника, на овај начин у великој мери решити економске изазове државе, с обзиром на то да ће милијарде долара које су се сваке године користиле за рад затвора користити за балансирање годишњег буџета државе и да је синдикат затворских чувара уверен да ће његовим члановима бити обезбеђена одржива запослења на другим местима унутар система, тако да не буду без посла. Да ли следи да и у овом утопистичком сценарију затвореници треба да буду пуштени пре него што су одслужили изречене казне?

12 http://www.vcgcb.ca.gov/restitution/: Приступљено 14. априла 2014. 
Одговор на ово питање зависи од тога колико озбиљно се узимају у обзир горе наведени концепти заслужености, одговорности и пропорционалне казне. Што се тиче пуштања на слободу, сама идеја ослобађања таквих затвореника било да би се балансирао државни буџет или зато што су затвореници заиста рехабилитовани (или оба) - садржи у себи негирање неких од основних моралних вредности које чине основу сваког разумно праведног друштва или друштва које жели постати разумно праведно. Питање које се овде разматра не узима у обзир шта криминалци заслужују на основу нивоа сопствене одговорности за оно што су урадили другима у смислу изазивања значајне штете. Тиме се крши уважавање принципа пропорционалне казне. Под претпоставком да су затвореници били осуђени и да су одговорни у значајној мери за оно што су урадили другима у смислу чињења кривичних дела, разматрање њиховог отпуста из било ког разлога крши принцип пропорционалне казне. Ово, поново, подразумева разумност казни које је изрекла држава. Питање превременог ослобађања криминалаца, дакле, не узима се у обзир када се ове основне моралне одредбе схвате озбиљно. Без обзира на то колико су мере штедње Калифорнији потребне, не треба да буду супротне ономе што правда захтева; не треба да негирају принцип заслужености, одговорности и пропорционалне казне. Сваки поуздан приступ балансирању калифорнијског буџета не сме довести у питање ова витална морална и правна питања.

Заиста, одїоворности без саосећана је безосећајна йрема криминалиима, али

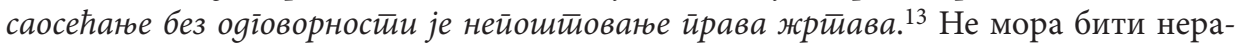
зрешивих противуречности између сматрања криминалаца одговорним за њихове грешке у мери у којој они јесу одговорни за њих, с једне стране, и поступања према њима прилично добро (барем у поређењу са другим затвореницима широм света), с друге стране. С обзиром на претпоставке које су већ постављене, ово подразумева да је идеја о раном отпусту криминалаца неоправдана, јер би криминалци требало да служе своје затворске казне као део онога што заслужују због онога што су урадили, када се у разматрање укључе све релевантне чињенице.

Ако је рани отпуст криминалаца и њихова условна слобода као морално питање ван разговора, да ли има других начина да се избегну економски проблеми са којима се суочава Калифорнија у вези са затворским системом који доприноси том проблему? Док постоје они који позивају на реформу затвора у смислу „права затвореника”, такав приступ, као што сам објаснио, само продубљује економске изазазове државе, а такође не узима озбиљно у обзир принципе одговорности и пропорционалне казне. Подршка правима затвореника, дакле, која није потпуно неоснована тамо где истински постоје злоупотребе у затворима, једва да се бави овим проблемом, стварајући друге озбиљне проблеме.

Реформа затвора у Калифорнији, тако да буду блажи према затвореницима, носи озбиљан ризик да не кажњава преступнике у складу са оним што пропорционалност диктира у светлу релевантних чињеница у њиховим случајевима. Штавише, не држи кривично осуђене криминалце одговорним за штету коју су нанели другима, узимајући у обзир све олакшавајуће факторе. Решење проблема није у томе

13 Жртве злочина, наравно, подразумевају директне и индиректне жртве, а штета настала услед злочина против њих може да има (и често има) трајне ефекте. 
да се једноставно обустави озбиљно кажњавање преступника, тамо где кажнавање подразумева строго поступање према њима (Feinberg, 1970). Реформа затвора мора да функционише у оба правца: мора да покуша да елиминише злостављање затвореника (проблем који се погоршава, како у погледу учесталости, тако и у погледу окрутности), али такође мора да настоји да они добију оно што су истински заслужили на основу чињеница у сваком појединачном случају, укључујући и озбиљност штете коју су нанели другима. Укратко, реформа затвора мора да укључи и реформу казнене политике. Док постоје случајеви у којима су криминалци претерано строго осуђени и кажњени (нарочито тамо где су расне и класне разлике присутне при изрицању казне преступницима), постоје бројни случајеви тешких злочина који нису довољно кажњени или је изречена претерано блага казна имајући у виду читав спектар чињеница и у светлу принципа пропорционалне казне. ${ }^{14}$ Шта ако реформа затвора, међутим, заједно усвоји и затвореничка права и одговорности? Уместо да се само труди да олакша ствари затвореницима, без обзира на злочине које су починили, систем би требало да их држи заиста одговорним за злочине по принципу пропорционалности, истовремено их штитећи од специфичних злоупотреба и злостављања у затвору. На крају крајева, док затворске казне не йреба да укључују кршење основних људских права починилаца, затворски услови йреба да представљају строги третман и разумни распон онога што то подразумева у смислу лишавања починилаца кривичних дела привилегија, а у светлу висине штете коју су нанели држави, грађанима и предузећима директно погођеним злочином. И теоретичари утилитаристичког принципа и принципа базираног на правичности могу се сложити око ове тачке (иако из различитих разлога, наравно), а потребан је аболиционистички (понекад постављен као рехабилитациони) став према казни да би се она негирала (Menninger, 1968; Boonin, 2008; Coleman, 2014). ${ }^{15}$ Закон, као и моралност, мора увек да очекује и захтева модикум разумности и правичности код когнитивно нормалних одраслих особа. Све што је од важности за могући рани отпуст и условну слободу затвореника у Калифорнији у погледу горе наведених фискалних циљева, принципа правичности, пропорционалности и одговорности мора се узети у обзир.

Постоји безброј начина да се тумаче клаузуле о окрутним и неуобичајеним казнама из осмог амандмана савезног Устава и Устава државе Калифорније. Вероватно су састављачи и ратификатори ових устава намерно изабрали да не буду прецизни у погледу оног што подразумевају под „окрутним и неуобичајеним”, као и код других важних термина из тих докумената. Један могући разлог за то је сама врста докумената, а састављачи и ратификатори су желели да оставе свакој генерацији грађана и законодаваца да сама одлучи шта представља окрутну и неуобичајену казну. ${ }^{16}$ Заиста, вероватно је да су састављачи и ратификатори имали дубоке несугласице међу собом у вези са значењем овог израза. Разумно је, онда, сматрати да фразе попут „окрутне и неуобичајене” треба да буду разматране кроз аргументе и анализе из једне генерације у другу. У светлу ове могућности, шта заправо представља окрутну

14 О таквим принципима више у Corlett, Responsibility and Punishment, 6. поглавље.

15 Овакав став је нарочито подржавао чувени адвокат Клеренс Дероу (Clarence Darrow).

16 Позајмио сам ову ставку из разговора са Џоелом Фајнбергом (Joel Feinberg) 1990. год. 
и неуобичајену казну у погледу изрицања казне и кажњавања озбиљних криминалаца у држави Калифорнији?

Неразумно је мислити да необезбеђивање медицинске заштите у обиму у коме је држава Калифорнија тренутно пружа затвореницима представља кршење клаузуле о окрутним и неуобичајеним казнама. ${ }^{17}$ Оно што се сматра окрутним и неуобичајеним јесте релативно питање. Лош је аргумент да је све што се дешава у другим „мање просветљеним” друштвима у смислу третмана у затворима морално погрешно, јер крши клаузулу о окрутним и неуобичајеним казнама. Зашто је окрутно и неуобичајено да се затвореницима не обезбеди онолико здравствених услуга колико је тренутно случај у држави Калифорнији, што је ниво здравствене заштите који не ужива више милиона грађана САД, да не спомињемо стотине милиона људи широм света? Према томе, зашто је кршење клаузуле о окрутним и неуобичајеним казнама да се затвореницима не пруже многе друге услуге које држава тренутно пружа? Поново, овде претпостављам да је свако лице правично осуђено за злочин које је починило и да му је изречена одговарајућа казна у светлу свих олакшавајућих фактора присутних у његовом случају.

Штавише, моралне интуиције се у великој мери разликују у погледу онога што се сматра пренатрпаношћу затвора и окрутним и неуобичајеним условима у затворском систему државе Калифорније. Када се принцип пропорционалности узме озбиљно, тешко је замислити како би изгледао разумни неупитни аргумент који је у складу са принципом пропорционалности, а који брани статус кво у затворима у Калифорнији у погледу пружања услуга кривичним прекршиоцима.

Која тачно морална права имају затвореници и која законска права треба да имају? Овим не мислим да питам која законска права поседују, пошто је одговор на то питање нешто што се тиче кривичних закона Калифорније (и савезних закона који су изнад њих). Пре свега, оно што желим да питам јесте која су њихова морална права, а то је још један начин да се пита која законска права они треба да имају. То је управо питање које, између осталог, подстиче преиспитивање онога што се сматра окрутним и неуобичајеним казнама.

Ако је фраза „потреба имплицира могућност” тачна, онда је неразумно да се од државе Калифорније очекује да обезбеди ниво здравствене заштите за затворенике који од ње тренутно очекује веће савезних судија, ако жели да се једног дана врати на дугорочну здраву и одрживу економију. Иако права не могу бити погажена због питања друштвене корисности (иначе, како тврди Џон Ролс (John Rawls), она не би била права), потраживање тих права није апсолутно. Контекст и околности морају утврдити њихову ваљаност. О овој тачки треба да мисле они који верују да генерално лоши економски услови често доводе до криминала и легитимно ублажавају казне за починиоце (в. Shelby, 2007, str. 126-160). Тако, они који имају овакав став треба да буду осетљиви на опадајуће здравље економских услова у Калифорнији, јер побољшање државне економије може на различите начине да помогне у превенцији

17 Имајте на уму да се овде не расправља о томе да због фискалних изазова у Калифорнији права затвореника на здравствену заштиту треба да буду прекршена како би се решили наведени изазови. То би било исто као када би се тврдило да се права могу кршити у екстремним ванредним ситуацијама, што је став који ефективно негира права. О питању значаја права над друштвено корисним (в. Rawls, 1971, str. 3-5). 
криминалних активности, генерално говорећи. Имамо у виду различите програме помоћи сиромашним грађанима (горе поменуте), од којих су неки показали важне резултате у превенцији криминала међу младима, пружајући многим грађанима наду за одрживу будућност. Ипак, да ли држава Калифорнија и даље може да приушти ниво медицинске и менталне здравствене заштите који тренутно пружа починитељима кривичних дела, а нарочито ниво медицинске и менталне здравствене заштите који би био значајно увећан? Чини се да то не може да учини у овом тренутку, с обзиром на високе трошкове здравствене заштите уопште.

Можда држава Калифорнија треба да преиспита тумачење клаузула о окрутним и неуобичајеним казнама, као и државну политику односа према затвореницима која је омогућила пружање изузетних здравствених услуга чак и најтежим преступницима. Можда држава Калифорнија мора да прикупи моралну храброст да одбаци као неразумно гледиште реформе затвора које ефективно не кажњава осуђене и одговорне злочинце у сразмери са њиховим злочинима, што ефективно подразумева и смањење нивоа здравствене заштите и одређених других услуга за такве затворенике. Можда држава Калифорнија мора да скупи моралну храброст да се чврсто држи својих разумних очекивања у погледу одговорности за понашање свих њених урачунљивих грађана (рачунајући олакшавајуће факторе), пружајући адекватну менталну заштиту онима којима је стварно потребна.

Међутим, оно за шта не постоји адекватан аргумент је тренутна ситуација у којој је држава Калифорнија у економским проблемима у значајној мери због тога што многи њени грађани, изабрани званичници, судије и други службеници за спровођење закона, одбијају да пруже разумне и неупитне аргументе који говоре у прилог томе да статус кво представља неправично кажњавање озбиљних криминалаца који су криви за своје злочине и штету коју су нанели другима. Док се то не постигне, тренутном систему кривичног правосућа је потребна реформа, али генерално не на начин ублажавања живота затвореника, већ у смислу да казне боље „осликавају” њихове злочине у погледу степена штете проузроковане другима. Ова мера производи жељени ефекат изрицања казни које су извршиоци заслужили (колико год то било приближно), без даљег гурања државе у банкротство.

На крају, чини се да проблем моралног статуса програма раног отпуста криминалаца почива на моралним интуицијама о томе шта представља окрутно и неуобичајено кажњавање у светлу онога што затвореници стварно заслужују у погледу штете коју су нанели другима. С једне стране, већина ће се сложити да, без обзира на кривично дело, без обзира на то колико је оно гнусно, погрешно и штетно за друге, такви преступници не треба да буду, рецимо, сакаћени, паљени и на друге начине физички мучени до смрти - чак иако би такве казне представљале лакше казне за неке окрутне и неуобичајене злочинце. Чак је и заступник ретрибутивистичке и смртне казне Имануел Кант тврдио да држава криминалце треба хумано да кажњава (Kant, 1965). Такође је морално контроверзно то да држава Калифорнија има моралну дужност да затвореницима пружи ниво здравствене заштите који тренутно пружа. То да би престанак пружања одређене робе и услуга затвореницима кршио наводна права затвореника је такође упитно. Поређења ради, већина затвора широм света је далеко мање погодна за затворенике него што су то затвори у Калифорнији. Чак и ако говоримо некомпаративно, није очигледно 
да садашње стање у затворима у Калифорнији крши „људска права” затвореника, или да је смањење броја услуга које држава пружа затвореницима кршење оних права која затвореници треба да имају, без обзира на класу, етничку припадност или род.

Различити су разлози због којих би држава Калифорнија могла да преиспита основне моралне вредности које су у основи њеног поступања према затвореницима и то би могло да се уради преиспитивањем тумачења клаузуле о окрутним и неуобичајеним казнама савезног и државног Устава. Престрого кажњавање озбиљних преступника знак је нехуманог друштва. Исто тако, превише је саосећајно друштво које - посебно усред озбиљних економских изазова - одбија да сакупи моралну храброст да казни своје криминалце према разумним принципима пропорционалне казне.

Иако је тачно да чињенице у случајевима многих затвореника захтевају ублажавање казне, таква разматрања се могу узети и узимају се у обзир при одређивању дужине казне. То не иде против идеје да прекршиоце треба казнити на начин који представља строго поступање и одузимање различитих привилегија и ефективно одрицање одређених права грађана који поштују закон. Штавише, то не негира идеју да држава Калифорнија превише троши на затварање озбиљних преступника. За оне који, рецимо, не желе смањење државног и градског буџета који се односи на јавно образовање, разумно је да сматрају да је далеко боље смањити буџет усмерен на кривичноправни систем. Можда би догматске идеологије требало да буду стављене у страну због разумне тежње према ономе што је праведно и поштено за државу Калифорнију и све њене грађане - како оне који поштују закон, тако и затворенике.

Не само да је упитно сматрати да рани отпуст и условна слобода великог броја затвореника пре одслужења казни штеде новац, постоје и различити начини на које се рад затвора може остварити по много нижој цени него што је тренутно случај у Калифорнији. Ако је тачно да је Удружење корективних службеника Калифорније (California Correctional Peace Officers Association-CCPOA) једно од најснажнијих у држави (Pens, 1998), можда је потребно значајно умањити утицај тог синдиката на државни буџет. Уколико би се у овом погледу смањио трошак казненог система, направио би се значајан напредак у смањивању трошкова калифорнијских затвора без имплементације програма за рани отпуст. Уштеда остварена на овај начин могла би се применити на трошкове проширења постојећих затвора под побољшаним условима у складу са одлуком суда.

Даља стратегија за смањење затворских трошкова у Калифорнији је трансфер затвореника са значајним клиничким менталним здравственим проблемима у установе за ментално здравље, где би били збринути на одговарајући начин. Иако би овај маневар смањио затворске трошкове, с друге стране би, вероватно, представљао значајан трошак пренет на државу у смислу трошкова психичког лечења за таква лица. Стручњаци за ментално здравље нису јефтини. Можда држава треба хумано да субвенционише адекватан третман таквих особа, јер је тешко тврдити да су они сами криви за своје менталне проблеме. Можда би пренос трошкова њиховог боравка у затворима на различите центре за лечење менталног здравља био довољан за лечење таквих особа - како стационарно тако и амбулантно. Третман, као што је овај, вероватно ће имати значајан и позитиван утицај на смањење броја самоубистава и масов- 
них пуцњава. Што је једнако битно, то би могло омогућити онима који пате од психичких проблема да преживе и живе смисленије, продуктивније и угодније животе.

Отпуст затвореника осуђених због кривичних дела у вези са наркотицима у програме за одвикавање од дрога стационарног типа који су базирани на заједници и надгледа их систем за условни отпуст, може уштедети држави милионе долара годишње, јер је измештање таквих особа из затвора у стационаре за рехабилитацију јефтиније за државу и много погодније за пацијенте. ${ }^{18}$ Осим ако такав третман не успе у значајном обиму, ова уштеда трошкова, међутим, не узима у обзир штету коју ће такви преступници нанети грађанима који поштују закон. То се може догодити у случајевима прекршаја као што је вожња у пијаном стању која може довести до смртних исхода или повреда грађана које, реално гледано, такви затвореници неће надокнадити. Овакав третман осуђених због кривичних дела у вези с наркотицима (измештање у стационаре за рехабилитацију) такође не узима у обзир стварне трошкове у виду многих провала и других сличних злочина које почине зависници од дрога пре завршетка успешног лечења. Трошкови раног отпуста у случајевима који су у вези са наркотицима у значајној мери преносе трошкове криминалитета са државе на приватне грађане који су жртве рецидивистичког понашања корисника дрога на програмима раног отпуста и условне слободе.

Наравно, постоји један начин који би омогућио и поштовање захтева правде у погледу казни и захтева за смањењем затворских трошкова: присиљавање затвореника да учествују у мануелним и другим облицима рада како би у што већој мери надокнадили затворске трошкове. То укључује ангажовање затвореника, рецимо, на јавним пројектима као што су изградња или поправка путева, мостова, на пословима берача или било каквим другим пословима где могу знатно помоћи у економском смислу. Многе државе већ намећу такав рад затвореницима по знатно нижој цени од синдикалног рада, чинећи присилни рад криминалаца добрим решењем за предузећа и затворенике (иако више за предузећа). Многе државе, попут Аризоне, пружају такву плаћену радну снагу. ${ }^{19}$ Међутим, интересантно је питање да ли државе треба да размишљају о нейлаћеном раgу који би се подстицао тако што би продуктивним затвореницима били омогућени различити облици слободног времена да се баве различитим затворским активностима које тренутно уживају, а не морају да зараде. Такав рад као облик кажњавања је, наравно, заштићен 13. амандманом Устава Сједињених Држава и Устава државе Калифорније (члан 1, одељак 18). Штавише, пошто „кажњавање” по дефиницији треба да буде найорно, онда не треба да се извињавамо што затвореници раде пуним радним временом без новчане накнаge. Уколико нису физички способни за мануелне послове, могу бити приморани да обављају што више немануелних послова како би надокнадили што већи део трошкова које намећу друштву све време док су у затвору. Читав њихов „доходак” настао из четрдесеточасовне радне недеље током целе године, у трајању служења казне, био би уплаћен директно држави Калифорнији као помоћ за смањење затворских трошкова. Са 5 долара по сату рада сваког запосленог затвореника, на око 100.000 затвореника

\footnotetext{
18 http://www.justicepolicy.org/images/upload/09_05_REP_PruningPrisons_AC_PS.pdf (приступљено 1. маја 2010)

19 http://www.azcorrections.gov/prisons/Prisca_Prisons_Perryvil.aspx/: Приступљено 14. априла 2014.
} 
који раде 40 сати недељно током целе године, могу се створити значајна средства која би, у суштини, значајно смањила затворске трошкове у Калифорнији. Заправо, затвореници би били присиљени да раде углавном мануелне послове - што је одличан начин да се науче да не чине злочине. Без обзира на износ који затвореник заради током затвора након исплате затворских трошкова, он би представљао новчану казну коју ће учинилац платити ако буде пуштен и који се враћа држави Калифорнији у износу до $50 \%{ }^{20}$ од зараде коју прими, док дуг не буде исплаћен у потпуности (већина затвореника ће умрети пре него што у потпуности плате своје дугове).

Наравно, као што тврдим на другим местима, онима који су погрешно затварани држава треба да обезбеди значајну компензацију и њихова кривична евиденција треба да се аутоматски избрише без трошкова по такве жртве кривичног правосудног система, а они који су кроз криминални немар били првенствено одговорни за њихово погрешно затварање морају да буду кажњени како је наведено у Казненом закону Калифорније уз одузимање имовине ради надокнаде жртвама које су неправедно биле затворене. Ако држава може добро да управља ресурсима заробљеника, постоји шанса да њихова радна снага може да произведе довољан вишак вредности (да употребимо терминологију Карла Маркса) како би надокнадила затворске трошкове чак и ако затвореник не може довољно да ради и у потпуности компензује своју жртву (жртве). Ово би научило одрасле починиоце да постану и остану одговорни грађани. Овај предлог представља облик „одговорног саосећања”, бар у смислу да систем не кажњава осуђене затворенике на строго пропорционалан начин.

Наравно, смањивање затворских трошкова представља само један начин на који држава Калифорнија може делом постати и остати фискално одговорна. Програме који спречавају криминалитет треба подржати као део целокупних напора да се задовоље буџетски захтеви, а такође треба осигурати да они функционишу у складу са кривичноправним системом. Различити програми за најугроженије којима је циљ постизање једнаких могућности, остварили су, и треба да наставе да остварују, значајан напредак у правцу отклањања услова који доводе до криминалних активности (Shelby, 2007). Држава мора да донесе овакве и друге одлуке како би поново постала и остала економски одржива. То захтева примену разумних закона и казни за оне који варају систем који је осмишљен да им помогне. За разлику од става оних који верују да је у неким случајевима „легитимно” када сиромашни прибегавају социјалним преварама те да је то напад на систем који многи сматрају неосетљивим на муке сиромашних (Shelby, 2007), свако суђење и изрицање казне за такву превару треба да узме у обзир да такви криминалци заправо лишавају друге сирома-шне грађане неопходних ресурса и тиме погоршавају њихов живот.

Потребно је предузети мере умереног карактера (одговорно саосећање) како би се балансирао државни приступ који води ка одрживом животу за све грађане. Не само да нема потребе за изградњом додатних затвора због тога што су неки (међу њима, извођачи радова на затворским објектима) уверили Калифорнију да је оно што неки сматрају пренатрпаношћу затвора „кршење људских права”, још неколико затвореника може бити смештено у већину постојећих затвора, чинећи их још мање

20 Овај проценат је у складу са оним што се узима од зараде сваког криминалца из различитих калифорнијских и савезних агенција како би се обезбедила реституција њиховим жртвама. Види http://www.vcgcb.ca.gov/restitution/: Приступљено 14. априла 2014. 
привлачним за свакога ко размишља да почини злочин. Оно што Калифорнији није потребно су додатни скупљи затвори (рецимо, они са максималним обезбеђењем, а по мојим сазнањима нема јефтиних затвора), што драматично повећава просечне затворске трошкове. Извођачи радова на затворским објектима морају да се бирају на основу најнижих понуда и треба укључити иностране конкуренте који могу да дају ниже понуде него што је случај већ неколико година. Ово подразумева да политичари на које „утичу” приватни извођачи и који желе да профитирају од изградње и одржавања затвора морају бити разоткривени, оптужени, процесуирани, и ако су прописно осуђени због своје преваре, кажњени значајним затворским казнама и присиљени да обезбеде реституцију држави.

Значајно смањење затворских трошкова елиминисањем различитих погодности за затворенике и њиховим присиљавањем на рад са пуним радним временом без компензације ни на који начин није злоупотреба људских права, нити кршење клаузула о окрутним и неуобичајеним казнама из савезног и државног Устава. Ради се, пре свега, о томе да се извршиоци злочина држе одговорним за незаконито повређивање других сразмерно штети коју су нанели. Затвореници могу економски да се експлоатишу како би се знатно умањила штета коју су нанели држави, грађанима и пословним жртвама, а у неким случајевима може доћи и до профита од њихових недела. Ипак, предузећима никада не сме бити дозвољено да остваре профит од затвореника све док се држави и жртвама злочина потпуно не надокнаде трошкови до којих су довели наведени затвореници. При томе, међу грађанима Калифорније мора да се развије прави осећај одговорног саосећања. У сваком случају, Калифорнија мора да одбије да настави да решава своју буџетску кризу, у мери у којој је она делимично резултат превеликих трошкова у вези са кривичним правосудним системом, преко леђа грађана који поштују закон. У најмању руку, државне порезе не треба повећавати како би се покрили увећани затворски трошкови све док се бар не размотре овде изложени предлози.

\section{REFERENCES / ЛИTEPATУPA}

Bernstein, S. (2013). Brown Must Reduce California Prison Population, Federal Judges

Rule. Reuters, April 12. Available at: http://www.freeinews.com/united-states/ brown-must-reduce-california-prison-population-federal-judges-rule

Boonin, D. (2008). The Problem of Punishment. Cambridge: Cambridge University Press. Coleman, S. (2014). Reality Check: Comparing California Prison Conditions to Other Countries. Burke Prison Break: Correctional Liability Update.

Corlett, J. A. (2014). Responsibility and Punishment. $4^{\text {th }}$ Edition, Dordrecht: Springer.

Davis, A. (2003). Are Prisons Obsolete? New York: Seven Stories Press.

Davis, A. (2005). Abolition Democracy. New York: Seven Stories Press.

Davis, L. (2011). California's Prisoner Shuffle. The Los Angeles Times, August 19. Available at: http://articles.latimes.com/2011/aug/19/opinion/la-oe-davis-prisoners-state-prisons-20110819 
Elias, P. (2013). California Prison Early Release Plan Won't Be Delaved, Supreme Court Rules. Huff Post, Los Angeles, August 2. Available at: http://www.huffingtonpost com/2013/08/02/california-prison-early-release_n_3698348.html

Feinberg, J. (1970). Doing and Deserving. Princeton: Princeton University Press.

Feinberg, J. (1973). Social Philosophy. Englewood Cliffs: Prentice-Hall.

Graves, S. (2013). Fewer State Prisoners, Higher Cost Per Inmate. California Budget Project, August 7. Available at: http://californiabudgetbites.org/2013/08/07/fewerstate-prisoners-higher-cost-per-inmate/

Justice Policy Institute (2010). Pruning Prisons: How Cutting Corrections Can Save Money and Protect Public Safety. Washington DC: Justice Policy Institute. Available at: http:// www.justicepolicy.org/images/upload/09_05_REP_PruningPrisons_AC_PS.pdf

Kant, I. (1965). The Metaphysical Elements of Justice. John Ladd, Trans., New York: Macmillan.

Menninger, K. (1968). The Crime of Punishment. New York: Viking.

Penner, G., Faryon, J. (2010). Soaring Costs For California's Failing Prison System. KPBS News, January 8. Available at http://www.kpbs.org/news/2010/jan/08/overcrowdedand-expensive-governor-addresses-calif/

Pens, D. (1998). The California Prison Guards' Union: A Potent Political Interest Group. in Daniel Burton-Rose (Ed.), The Celling of America, Common Courage Press.

Rawls, J. (1971). A Theory of Justice. Cambridge: Harvard University Press.

Shelby, T. (2007). Justice, Deviance, and the Dark Ghetto. Philosophy \& Public Affairs, 35 (2007), pp. 126-160.

Thompson, D. (2013). Calif. Struggles with Experiment to Shift Inmates. Associated Press, May 12. Available at:http://news.yahoo.com/calif-struggles-experiment-shiftinmates-133428169.html

Thompson, D. (2014). California Prisons Find 1 in 4 Inmates Used Drugs. The Sacramento Bee, April 14. Available at:http://www.sacbee.com/2014/04/07/6303884/californiaprisons-find-1-in-4.html 